\title{
Seasonal variations in some quality parameters of milk produced in Khorasan Razavi Province, Iran
}

\author{
Marzieh HAJMOHAMMADI ${ }^{1}$, Reza VALIZADEH ${ }^{1}$, Mohammad Norouzi EBDALABADI ${ }^{2}$, Abassali NASERIAN ${ }^{1}$, \\ Carlos Augusto Fernandes de OLIVEIRA ${ }^{3 *}$ (D)
}

\begin{abstract}
In this trial, 60 samples of raw cow's milk collected during summer and winter in five collective centers from Khorasan Razavi Province of Iran were analyzed for penicillin residues, somatic cell counts (SCC), mesophilic counts (TMC) and adulteration materials. The mean penicillin level $(0.57 \pm 0.20 \mu \mathrm{g} / \mathrm{L})$ was much lower than the maximum permitted level (MPL) recommended by the Codex Alimentarius Commission $(4 \mu \mathrm{g} / \mathrm{L})$. However, the mean SCC and TMC (Log $5.71 \pm 0.08 \mathrm{cells} / \mathrm{mL}$ and Log $6.18 \pm 0.11$ colony forming units $(\mathrm{CFU}) / \mathrm{mL}$, respectively) exceeded their respective MPLs adopted in Iran for grade $\mathrm{C}$ milk (Log 5.69 cells $/ \mathrm{mL}$ and Log 6.0 CFU/mL, respectively), with higher counts $(P<0.05)$ in the summer. High frequencies of samples containing salt (53-60\%), detergents (16-20\%) and formalin (7-10\%) were observed in milk samples, stressing the need for stringent control measures to improve the quality of milk delivered in the evaluated collection centers.
\end{abstract}

Keywords: antibiotic residue, somatic cell counts, mesophilic counts, milk adulteration.

Practical Application: Occurrence data on penicillin residues, mesophilic bacteria, SCC and adulterants in Iranian milk.

\section{Introduction}

Cow's milk as the most important product of dairy systems is among the main foods for human consumption all over the world (Pereira, 2014). Because of its high nutritional value, milk offers excellent conditions for microbial growth, thus requiring proper conservation to avoid rapid deterioration by spoilage microorganisms and pathogenic bacteria (Lee et al., 2019). One of the most important contaminants of milk and dairy products are mesophilic bacteria, including several types of pathogens like Salmonella spp. and Mycobacterium spp. (Lee et al., 2012; Moosavy et al., 2019; Mullan, 2019). Moreover, milk may also contain increased somatic cell counts (SCC), mainly formed by leukocytes from blood origin and epithelial cells from scaling-off as a consequence of inflammation of the mammary gland (Fagundes et al., 2011). In this context, total mesophilic count (TMC) and SCC have been defined as the most reliable indicators for evaluating the quality of raw milk received in dairy processing factories worldwide, especially in the developed countries (Coelho et al., 2017). In the Iranian milk production system, raw milk is categorized into four grades (excellent, A, $B$ and $C$ ), depending on maximum permitted levels (MPL) for SCC and TMC (Institute of Standard and Industrial Research of Iran, 2014). The higher MPLs were established for grade C milk, which should contain maximum SCC and TMC levels of $10^{5}$ cells $/ \mathrm{mL}$ (Log 5.69 cells $/ \mathrm{mL}$ ) and $10^{6}$ colony forming units $(\mathrm{CFU}) / \mathrm{mL}(\log 6.0 \mathrm{CFU} / \mathrm{mL})$, respectively (Institute of Standard and Industrial Research of Iran, 2014).
The main contributing factors for microbial contamination of raw milk are related to milking hygiene and parlous conditions, cow udder soundness, raw milk collection, reserving and handling to the processing factories (Tassew \& Seifu, 2011; Kara \& Aslan, 2020). Additionally, milk and dairy products are exposed to different chemical contaminants such as antibiotics and other drug residues, neutralizing and preservatives residues (Iqbal, 2017; Müller et al., 2020). Among these contaminants, antibiotics residues represent a worldwide concern, since they are broadly used to control, treat or prevent different diseases, increase growth rate, regulate reproduction, or even improve the production efficiency of the dairy animals (Oliveira et al., 2020). The issue of antibiotic residues in milk is not a new problem. In the early 1960 's, over $6 \%$ of the raw milk marketed in the United States were contaminated with antibiotic residues, although recent surveys indicated that the contamination percentage in the country decreased to $3.7 \%$ (Grunwald \& Petz, 2003). Previous studies conducted in Iran indicated that antibiotic residues have been occasionally detected in raw cow's milk (Ghanavi et al., 2013; Moghadam et al., 2016).

Adulteration of milk is known as unethical activities conducted by producers aiming to increase the milk yield or reduce losses due to milk spoilage during storage and transportation (Swathi \& Kauser, 2015). Typical examples of milk adulteration include the addition of water to increase milk yield, incorporation of salt or other thickening agents 
such as starch to restore the physical-chemical parameters of water-diluted milks, and the addition of chemical preservatives like hydrogen peroxide, caustic soda, detergents and formalin (Iqbal, 2017). In Iran, adulteration practices of raw milk have been recently documented in the provinces of East Azerbaijan (Mahmoudi et al., 2015), Qazvin (Panahzadeh et al., 2016) and in the Iranian northwest region (Moosavy et al., 2019). However, there is little information on the occurrence of adulteration practices along with other quality parameters of milk produced in the Iranian Province of Khorasan Razavi, which is one of the most important milk producers in Iran. Therefore, the aim of this study was to evaluate the presence of penicillin residues, TMC, SCC and the addition of adulteration materials in cow's milk produced during summer and winter in Khorasan Razavi Province of Iran.

\section{Material and methods}

\subsection{Sampling procedures}

During the winter and summer of year 2018, 60 random milk samples $(500 \mathrm{~mL})$ were collected from raw bulk milk tanks in five collective centers in the region of Mashhad city, Khorasan Razavi Province of Iran. The main characteristics of the collective centers and their respective dairy herds are described elsewhere (Hajmohammadi et al., 2020). Briefly, each collective center received the raw milk from 15 - 30 dairy farms (mean milk production: 5,000 - 10,000 L/day), and the majority of dairy herds were pure or half-breed Holstein Friesian dairy cattle. The samples were collected every month for 12 months (one sample per tank), totaling 30 samples of raw milk collected in each season. After identification, samples were placed in isothermal containers with ice and immediately transported to the Ferdowsi University of Mashhad central laboratory for analysis.

\subsection{Determination of penicillin residues}

Preparation of milk samples and the required standard solutions of penicillin were performed according to the instructions for the fast ELISA penicillin kit (5091 PEN) manufactured by Europroxima (Arnhem, The Netherlands). Milk samples $(250 \mu \mathrm{L})$ were diluted with $250 \mu \mathrm{L}$ of buffer provided with the kit and vortexed for a few seconds. Fifty microliters of standard solutions (prepared in dilution buffer provided by the kit at levels of 0 , $0.125,0.25,0.5,1,2$ and $4 \mu \mathrm{g} / \mathrm{L}$ ) and milk samples were added to the wells of a polystyrene microtiter plate. Then, $25 \mu \mathrm{L}$ of the enzyme conjugate and $25 \mu \mathrm{L}$ of the antibody solution were added to each well (except $\mathrm{H} 1$ and $\mathrm{H} 2$ ) and mixed thoroughly in a microtiter plate shaker for a few seconds. This solution was incubated in the dark at $4 \mathrm{oC}$ for 1 hour. After this period, $100 \mu \mathrm{L}$ of the substrate solution were added to each well, mixed thoroughly and incubated in the dark at $25^{\circ} \mathrm{C}$ for 30 minutes. Finally, $100 \mu \mathrm{L}$ of the stop solution were added into each well, and its absorbance read at $450 \mathrm{~nm}$ in an ELISA plate reader (ELX800, Bio-Tek Instruments, Winooski, VT) against air blank within 15 minutes. The detection limit of the assay was $0.08 \mu \mathrm{g} / \mathrm{L}$ of milk.

\subsection{Determination of total mesophilic bacteria and somatic cell counts}

Analysis of TMC in milk was conducted strictly following the procedures as described by American Public Health Association (2004). One mL of raw milk sample was transferred into a sterile test tube containing $9 \mathrm{~mL}$ of peptone water. After mixing, the sample was serially diluted up to 1:10-7 and aliquots $(1 \mathrm{~mL})$ were pour plated using $15-20 \mathrm{~mL}$ standard plate count agar (Oxoid) and mixed thoroughly. The plates were then incubated at $30^{\circ} \mathrm{C}$ for $48 \mathrm{~h}$. Colony counts were accomplished using a colony counter.

SCC was determined using a SOMATOS-M viscometric analyzer (Biomer, Krasnoobsk, Russia). Determination of milk adulterants Raw milk samples adulterants such as formalin, hydrogen peroxide, sodium bicarbonate, starch, detergents and salt were detected in milk according to the Iranian standard protocols (Farkhondeh, 2007).

\subsection{Statistical analysis}

The obtained data on penicillin residues, TMC, SCC and detection of milk adulteration in the summer and winter seasons were analyzed as nonparametric tests, followed by Mann-Whitney tests using SPSS software version 20 (SPSS Inc, Chicago, IL, USA). All statements of significance were based on the 0.05 level of probability.

\section{Results and discussion}

The frequency and levels of penicillin residues in cow's milk produced in Khorasan Razavi Province of Iran are presented in Table 1. Penicillin residues were found in $100 \%$ and $97 \%$ of samples analyzed in the summer and winter, respectively, although at low levels $(0.77 \pm 0.23 \mu \mathrm{g} / \mathrm{L}$ and $0.37 \pm 0.16 \mu \mathrm{g} / \mathrm{L}$ in summer and winter, respectively), with an overall mean of $0.57 \pm 0.23 \mu \mathrm{g} / \mathrm{L}$ in all samples. However, there were no differences $(P>0.05)$ between the penicillin levels in milk samples collected in different seasons. By using a qualitative kit assay, Moghadam et al. (2016) observed that $38.5 \%$ of cow's raw milk samples collected from collection centers in Gonabad city located at the south of the Iranian Khorasan Razavi Province tested positive for antibiotics residues. Our results are different from those reported by Ghanavi et al. (2013), who reported nearly $11 \%$ of cow's milk samples from different Iranian

Table 1. Occurrence of penicillin residues in cow's milk produced during the winter and summer seasons in Khorasan Razavi Province of Iran.

\begin{tabular}{lccccc}
\hline \multicolumn{1}{c}{ Season } & $\boldsymbol{n}$ & $\%$ & $\begin{array}{c}\text { Mean } \pm \mathrm{SD} \\
(\mu \mathrm{g} / \mathrm{L})\end{array}$ & $\begin{array}{c}\text { Concentration } \\
\text { range }(\mu \mathrm{g} / \mathrm{L})\end{array}$ & $\begin{array}{c}\boldsymbol{n}>\mathrm{MPL} \\
(\%)\end{array}$ \\
\hline Summer $(N=30)$ & 30 & 100 & $0.37 \pm 0.16$ & $<\mathrm{LOD}-5.00$ & $1(3)$ \\
Winter $(N=30)$ & 29 & 97 & $0.77 \pm 0.23$ & $0.05-5.00$ & $2(6)$ \\
Total $(N=60)$ & 59 & 98 & $0.57 \pm 0.20$ & $<\mathrm{LOD}-5.00$ & $3(5)$ \\
\hline
\end{tabular}

No significantly difference was found between the means $(P>0.05) . n=$ number of positive samples. SD $=$ Standard deviation. LOD: Limit of detection: $0.08 \mu \mathrm{g} / \mathrm{L}$. MPL: Maximum permitted level $(4.0 \mu \mathrm{g} / \mathrm{L})$ adopted by European countries (European Commission, 2010). 
regions contained penicillin G residues (mean level: $1.2 \mu \mathrm{g} / \mathrm{L}$ ). In our study, three samples (two collected in the winter and one collected in the summer) were higher than the MPL ( $4 \mu \mathrm{g} / \mathrm{L})$ recommended by the Codex Alimentarius Commission (2020). These data reinforce the need for Iranian regulations as well as the adoption of control strategies to prevent high levels of antibiotic residues in the milk produced in the country.

Table 2 presents the SCC obtained in cow's milk samples collected in Province of Khorasan Razavi. Considering the SCC obtained in both seasons, the overall mean (Log $5.71 \pm 0.08$ cells $/ \mathrm{mL}$ ) was above the MPL established by European Union (EU) ( $\log 4.0$ cells $/ \mathrm{ml}$ ). In summer, the mean SCC in milk samples ( $\log 5.75 \pm 0.07$ cells $/ \mathrm{mL}$ ) was higher $(P<0.05)$ than the value obtained in the winter season $(\log 5.69 \pm 0.06$ cells $/ \mathrm{mL})$, with $63 \%$ of all values above the MPL of Log 5.69 cells/mL adopted in Iran for grade C milk (Institute of Standard and Industrial Research of Iran, 2014). A previous study conducted in Mashhad city indicated no significant differences in the milk SCC collected in summer or winter seasons (Najafi et al., 2009).

Our results are in agreement with those described by Salman \& Elnasri (2011) in the Khartoum State of Sudan, where higher SCC was found in bulk raw milk samples collected in summer ( $\log 5.78$ - 5.90 cells/mL), compared with winter ( $\log 5.72$ - 5.88 cells $/ \mathrm{mL}$ ). The authors hypothesized that the higher SCC found in summer samples of bulk milk was associated with mixtures of individual milks from different farms with high incidence of subclinical mastitis. However, it is well known that higher SCC in summer coincides with increased cases of clinical mastitis in summer months (Olivo et al., 2005; Fagundes et al., 2011), which could explain the season effect on the SCC data obtained in the present study.

Table 3 presents the TMC of cow's milk produced during the winter and summer seasons in Khorasan Razavi Province of Iran. The overall TMC mean was $\log 6.18 \mathrm{CFU} / \mathrm{mL}$, which is above the MPL of Log 6.0 CFU/mL adopted by Iranian regulations for grade $\mathrm{C}$ milk (Institute of Standard and Industrial Research of Iran, 2014). The samples collected in summer had higher $(P<0.05)$ mean TMC (Log 6.05 to $6.38 \mathrm{CFU} / \mathrm{mL}$ ) than the mean value obtained in winter samples (Log 5.99 to $6.33 \mathrm{CFU} / \mathrm{mL}$ ). Importantly, all samples had TMC above the EU standard guidelines ( Log 5.69 $\mathrm{CFU} / \mathrm{mL}$ ). These results indicate that most of the traditional milk production in the studied region is accomplished under

Table 2. Somatic cell counts (SCC) of cow's milk produced during the winter and summer seasons in Khorasan Razavi province of Iran.

\begin{tabular}{lccc}
\hline \multicolumn{1}{c}{ Season } & $\begin{array}{c}\text { SCC mean } \pm \text { SD } \\
(\mathbf{L o g} \text { cells } / \mathbf{m L})\end{array}$ & $\begin{array}{c}\text { SCC concentration } \\
\text { range }(\log \text { cells/mL) }\end{array}$ & $\begin{array}{c}\boldsymbol{n}>\text { MPL } \\
(\%)\end{array}$ \\
\hline Summer $(N=30)$ & $5.75 \pm 0.07^{\mathrm{a}}$ & $5.65-5.87$ & $22(73)$ \\
Winter $(N=30)$ & $5.69 \pm 0.06^{\mathrm{b}}$ & $5.54-5.79$ & $16(53)$ \\
Total $(N=60)$ & $5.71 \pm 0.08$ & $5.54-5.87$ & $38(63)$ \\
\hline
\end{tabular}

a-b Mean values within rows with no common superscript differ significantly $(P<0.05)$. $\mathrm{SD}=$ Standard deviation. MPL: Maximum permitted level (Log 5.69 cells $/ \mathrm{mL})$ adopted by Iranian regulations for grade C milk (Institute of Standard and Industrial Research of Iran, 2014). unsatisfactory sanitary conditions. This is illustrated by the fact that the majority of cow's milk producers in the Province of Korazan Razavi transport and deliver the raw milk to collective central in small containers, which are not submitted to sanitizyn procedures but only rinsed with water. Therefore, the poor hygienic conditions of raw milk transportation may be considered among the most important contributing factors for the high TMC observed in the present study. Highly contaminated raw milks may contain many pathogens such as Listeria monocytogenes and Staphylococcus aureus, which are among the major causes of foodborne illness worldwide (Shabbir et al., 2020). Coherently, the higher TMC and SCC in raw milk samples collected in summer as described here are similar to the data reported in Sudan (Salman \& Elnasri, 2011) and Ethiopia (Tassew \& Seifu, 2011). In addition, the microbiological quality of raw milk depends on the proper management of dairy herds, hygienic milking of healthy dairy cows and immediate cooling of milk in the farm (Camargo et al., 2014). Since in the present study the sampling procedures were conducted in collection centers, it remains to be determined to what extent these farm-related factors could have contributed for increasing the TMC in the raw milk samples evaluated.

In this study, raw milk samples were evaluated for the detection of unhealthy and inexpensive additives that may be used with the porpoise of extending the raw milk shelf-life or hide fraud practices. The results are present in Figure 1, indicating that raw milk collected in winter and summer was contaminated with several extraneous materials such as detergents ( 16 and $20 \%$, respectively), hydrogen peroxide (6 and $3 \%$, respectively), salt (53 and 60\%, respectively) and formalin (7 and 10\%, respectively). However, the analysis of other additives in milk samples including starch and sodium bicarbonate tested negative. Overall, there was no difference $(P>0.05)$ in the percentages of positive samples for adulteration parameters in the summer and winter. These results indicate that adulteration practices of raw milk are frequently adopted over the year in the milk production system of Khorasan Razavi, as previously reported by Mahmoudi et al. (2015) and Panahzadeh et al. (2016) regarding the milk produced in the Iranian provinces of East Azerbaijan and Qazvin, respectively.

Similarly to our results, milk adulteration has been widely reported in developing countries such as Sudan (Ibtisam et al.,

Table 3. Total mesophilic counts (TMC) of cow's milk produced during the winter and summer seasons in Khorasan Razavi province of Iran.

\begin{tabular}{cccc}
\hline Season & $\begin{array}{c}\text { TMC mean } \pm \text { SD } \\
(\text { Log CFU/mL) }\end{array}$ & $\begin{array}{c}\text { TMC concentration } \\
\text { range }(\text { Log CFU } / \mathbf{m L})\end{array}$ & $\begin{array}{c}n>\text { MPL } \\
(\%)\end{array}$ \\
\hline Summer $(N=30)$ & $6.25 \pm 0.07^{\mathrm{a}}$ & $6.05-6.38$ & $30(100)$ \\
Winter $(N=30)$ & $6.10 \pm 0.11^{\mathrm{b}}$ & $5.99-6.33$ & $26(87)$ \\
Total $(N=60)$ & $6.18 \pm 0.11$ & $5.99-6.38$ & $56(93)$ \\
\hline
\end{tabular}

a-b Mean values within rows with no common superscript differ significantly $(P<0.05)$. $\mathrm{cfu}$ : colony forming units. $\mathrm{SD}=$ Standard deviation. MPL: Maximum permitted level (Log 6.0 CFU/mL) adopted by Iranian regulations for grade C milk (Institute of Standard and Industrial Research of Iran, 2014). 


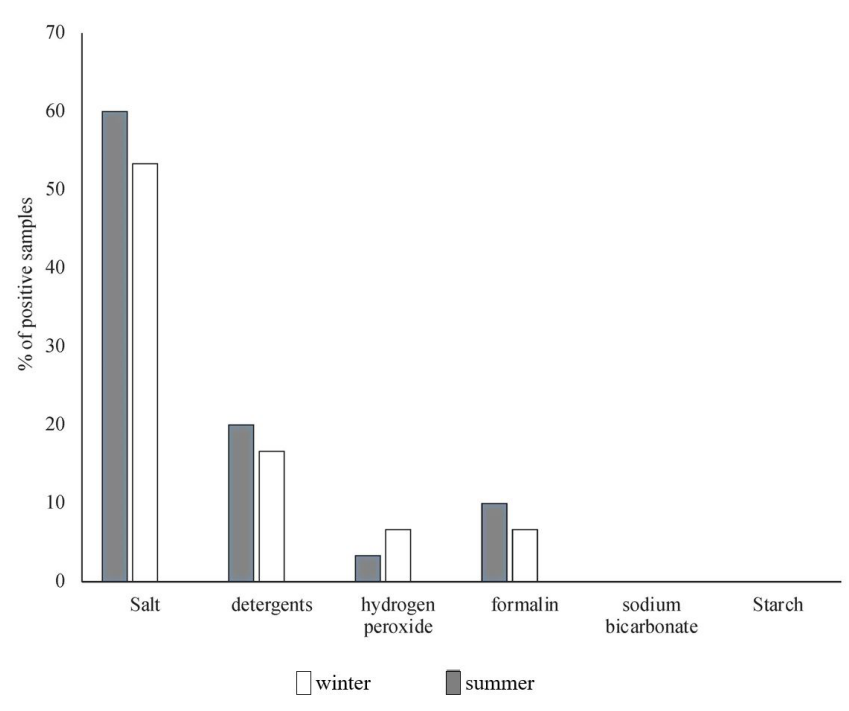

Figure 1. Percentages of samples with detectable adulterants in cow's milk from Khorasan Razavi province of Iran, collected in winter and summer ( $n=30$ in each season). Values among winter or summer seasons were not different $(P>0.05)$.

2009), India (Swathi \& Kauser, 2015) and Pakistan (Barham et al., 2014; Iqbal, 2017). However, the percentage of positive samples containing formalin $(2.4 \%)$ and hydrogen peroxide $(0.4 \%)$ obtained by Ibtisam et al. (2009) in Sudan was lower than those reported here. High percentages (up to 100\%) of adulterants including water, starch and detergents were found in milk from local vendors in India (Swathi \& Kauser, 2015). In a similar study conducted in Pakistan, Barham et al. (2014) observed higher percentages of samples containing adulterants such as detergents (41\%), starch (27\%), formalin (20\%), hydrogen peroxide (15\%), caustic soda (11\%), glucose (10\%) and hypochlorite (5\%). These data indicate that continuous monitoring programs are required in Iran among other developing countries, to inhibit milk adulteration practices. Given the diversity of potential adulterants in milk, the use of automatic instruments should be considered for robust detection of frauds in raw milk (Nascimento et al., 2017).

\section{Conclusion}

Although penicillin residues were frequently detected in all samples analyzed, the levels found were low and only three samples had concentrations above the MPL adopted in European countries $(4.0 \mu \mathrm{g} / \mathrm{L})$. There were seasonal variations in the TMC and SCC in milk, with higher levels observed in samples collected in summer. However, TMC and SCC obtained in both seasons were higher than the MPLs set up by European Communities and Iran regulations. These results in association with the high occurring percentages of adulterants in raw milk such as hydrogen peroxide, salt, formalin and detergents, stress the need for urgent control measures in the milk production system in Khorasan Razavi province, with special oversee on the collective centers of raw milk.

\section{Acknowledgements}

The authors thank the Ferdowsi University of Mashhad, Department of Animal Science Agricultural and Natural Resources Research, and the Education Center of Khorasan-e Razavi of Mashhad, for their financial supports.

\section{References}

American Public Health Association (2004). Standard methods for the examination of dairy products (17th ed.). Washington, USA: APHA. https://doi.org/10.2105/9780875530024.

Barham, G. S., Khaskheli, M., Soomro, A. H., \& Nizamani, Z. A. (2014). Detection and extent of extraneous water and adulteration in milk consumed at Hyderabad, Pakistan. Journal of Food and Nutrition Sciences, 2(2), 47-52. http://dx.doi.org/10.11648/j.jfns.20140202.15.

Camargo, T. M., Barancelli, G. V., Dalloca, L. I., Oliveira, C. A. F., \& Porto, E. (2014). Occurrence of Listeria monocytogenes, total coliforms, Escherichia coli, and production and storage processes of raw milk from dairy farms in the state of São Paulo, Brazil. African Journal of Microbiological Research, 8(29), 2766-2771. http://dx.doi.org/10.5897/AJMR2014.6769.

Codex Alimentarius Commission. (2020). International food standards: Index of veterinary drugs. Rome: $\mathrm{FAO} / \mathrm{WHO}$. Retrieved from http:// www.fao.org/fao-who-codexalimentarius/codex-texts/dbs/vetdrugs/ veterinary-drugs/en/

Coelho, V. R. P., Rodrigues, C. E. C., Corassin, C. H., Balthazar, C. F., Cappato, L. P., Ferreira, M. V. S., Cruz, A. G., \& Oliveira, C. A. F. (2017). Milk with different somatic cells counts and the physicochemical, microbiological characteristics and fatty acid profile of pasteurized milk cream: is there an association? International Journal of Food Science \& Technology, 52(12), 2631-2636. http://dx.doi.org/10.1111/ijfs.13550.

European Commission (2010). Commission Regulation (EU) No $37 / 2010$ of 22 December 2009 on pharmacologically active substances and their classification regarding maximum residue limits in foodstuffs of animal origin. Official Journal of the European Union, $L, 15,1$.

Fagundes, H., Barchesi, L., Corassin, C. H., \& Oliveira, C. A. F. (2011), Microbiological analysis and somatic cell count in raw milk from farms of São Paulo State, Brazil. African Journal of Microbiological Research, 5, 3542-3545. http://dx.doi.org/10.5897/AJMR11.722.

Farkhondeh, A. (2007). Methods of testing milk and its products. Tehran: University of Tehran Publications.

Ghanavi, Z., Mollayi, S., \& Eslami, Z. (2013). Comparison between the amount of penicillin $G$ residue in raw and pasteurized milk in Iran. Jundishapur Journal of Microbiology, 6(7), 124-127. http://dx.doi.org/10.5812/jjm.12724.

Grunwald, L., \& Petz, M. (2003). Food processing effects on residues: penicillin in milk and yoghurt. Analytica Chimica Acta, 483(1-2), 73-79. http://dx.doi.org/10.1016/S0003-2670(02)01405-8.

Hajmohammadi, M., Valizadeh, R., Naserian, A., Nourozi, M. E., Rocha, R. S., \& Oliveira, C. A. F. (2020). Composition and occurrence of aflatoxin $\mathrm{M}_{1}$ in cow's milk samples from Razavi Khorasan Province, Iran. International Journal of Dairy Technology, 73(1), 40-45. http://dx.doi.org/10.1111/1471-0307.12661.

Ibtisam, E., El Zubeir, M., \& El Owni, O. A. O. (2009). Antimicrobial resistance of bacteria associated with raw milk contaminated by chemical preservatives. World Journal of Dairy and Food Sciences, 4, 65-69.

Institute of Standard and Industrial Research of Iran (2014). Microbiology of milk and milk products specifications no. 2406 (pp. 1-10). Tehran: ISIRI. 
Iqbal, F. (2017). Milk adulteration: A growing health hazard in Pakistan. In R. R. Watson, R. J. Collier \& V. R. Preedy (Eds.), Nutrients in dairy and their implications on health and disease (pp. 215-212). https://doi.org/10.1016/B978-0-12-809762-5.00017-6

Kara, R., \& Aslan, S. (2020). Investigation of Listeria monocytogenes in workers, equipment and environments at Kaymak processing plants. Food Science and Technology. In press. http://dx.doi.org/10.1590/fst.02620.

Lee, S. H., Camargo, C. H., Gonçalves, J. L., Cruz, A. G., Sartori, B. T., Machado, M. B., \& Oliveira, C. A (2012). Characterization of Staphylococcus aureus isolates in milk and the milking environment from small-scale dairy farms of São Paulo, Brazil, using pulsed-field gel electrophoresis. Journal of Dairy Science, 95(12), 7377-7383. http://dx.doi.org/10.3168/jds.2012-5733. PMid:23040016.

Lee, S. H. I., Cruz, A. G., Cappato, L. P., Guimarães, J. T., Balthazar, C. F., Rocha, R. S., Corassin, C. H., Franco, L. T., \& Oliveira, C. A. F. (2019). Listeria monocytogenes in milk: occurrence and recent advances in methods for inactivation. Beverages, 5(1), 14. http://dx.doi.org/10.3390/beverages5010014.

Mahmoudi, R., Shahri, M. K. K., Moosavy, M. H., \& Norian, R. (2015). Analysis of adulteration in raw cow milk samples collected from East Azerbaijan Province of Iran. International Journal of Food Nutrition and Safety, 6, 150-156.

Moghadam, M. M., Amiri, M., Riabi, H. R. A., \& Riabi, H. R. A. (2016). Evaluation of antibiotic residues in pasteurized and raw milk distributed in the South of Khorasan-e Razavi Province, Iran. Journal of Clinical and Diagnostic Research: JCDR, 10(12), 31-35. http://dx.doi.org/10.7860/JCDR/2016/21034.9034. PMid:28208877.

Moosavy, M. H., Kordasht, H. K., Khatibi, S. A., \& Sohrabi, H. (2019). Assessment of the chemical adulteration and hygienic quality of raw cow milk in the northwest of Iran. Quality Assurance and Safety of Crops \& Foods, 11(5), 491-498. http://dx.doi.org/10.3920/ QAS2019.1605.

Mullan, W. M. A. (2019). Are we closer to understanding why viable cells of Mycobacterium avium subsp. paratuberculosis are still being reported in pasteurised milk? International Journal of Dairy Technology, 72, 332-344. http://dx.doi.org/10.1111/14710307.12617.

Müller, P. M., Medeiros, E. S., Mota, R. A., Rolim, M. B. Q., Colombo, M. V., Rübensam, G., Barreto, F., Silva, D. D., \& Silva, T. I. B. (2020). Avermectins residues in milk produced in the state of Pernambuco. Food Science and Technology. In press. https://dx.doi.org/10.1590/ fst.21919.
Najafi, M. N., Mortazavi, S. A., Koocheki, A., Khorami, J., \& Rekik, B. (2009). Fat and protein contents, acidity and somatic cell counts in bulk milk of Holstein cows in the Khorasan Razavi Province. International Journal of Dairy Technology, 62(1), 19-26. http://dx.doi.org/10.1111/j.1471-0307.2008.00451.x.

Nascimento, W. W. G., Souza, M. P. F., Valente, A. C. M. M., Anjos, V. C., Furtado, M. A. M., \& Bell, M. J. V. (2017). Results from portable and of low cost equipment developed for detection of milk adulterations. Food Science and Technology (Campinas), 37(spe), 38-41. http://dx.doi.org/10.1590/1678-457x.06617.

Oliveira, N. A., Gonçalves, B. L., Lee, S. H. I., Oliveira, C. A. F., \& Corassin, C. H. (2020). Use of antibiotics in animal production and its impact on human health. Journal of Food Chemistry and Nanotechnology, 6(01), 40-47. http://dx.doi.org/10.17756/jfcn.2020-082.

Olivo, C. J., Beck, L. I., Gabbi, A. M., Charão, P. S., Sobczak, M., Uberty, L. F. G., Dürr, J. W., \& Araújo, R. Fo (2005). Composition and somatic cell count of milk in conventional and agro-ecological farms: A comparative study in Depressão Central, Rio Grande do Sul state, Brazil. Livestock Research, 17(6), 1-7. Retrieved from http://www.lrrd.org/lrrd17/6/oliv17072.htm.

Panahzadeh, P., Ghajarbeygi, P., \& Mahmoudi, R. (2016). Detection of adulteration in raw cow milk supplied in the Qazvin province, Iran, during (2015-2016). Carpathian Journal of Food Science and Technology, 8, 26-32.

Pereira, P. (2014). Milk nutritional composition and its role in human health. Nutrition (Burbank, Los Angeles County, Calif.), 30(6), 619627. http://dx.doi.org/10.1016/j.nut.2013.10.011. PMid:24800664.

Salman, A., \& Elnasri, H. A. (2011). Somatic cell count, total bacterial count and acidity properties of milk in Khartoum State, Sudan. Journal of Cell and Animal Biology, 13, 223-230. Retrieved from https:// academicjournals.org/journal/JCAB/article-full-text-pdf/11543B513579

Shabbir, M. A., Ahmed, H., Maan, A. A., Rehman, A., Afraz, M. T., Iqbal, M. W., Khan, I. M., Amir, R. M., Ashraf, W., Khan, M. R., \& Aadil, R. M. (2020). Effect of non-thermal processing techniques on pathogenic and spoilage microorganisms of milk and milk products. Food Science and Technology. http://dx.doi.org/10.1590/fst.05820.

Swathi, J. K., \& Kauser, N. (2015). A study on adulteration of milk and milk products from local vendors. International Journal of Biomedical and Advance Research, 6, 678-681.

Tassew, A., \& Seifu, E. (2011). Microbial quality of raw cow's milk collected from farmers and dairy cooperatives in Bahir Dar Zuria and Mecha district, Ethiopia. Agriculture and Biology Journal of North America, 2(1), 29-33. http://dx.doi.org/10.5251/abjna.2011.2.1.29.33. 